\title{
Putting the "Queen” Back Into Queensland
}

\author{
Harry Hobbs
}

On 3 April 2012, the Honourable Member for Kawana, Jarrod Bleijie MP, was sworn in as Attorney-General for Queensland and Minister for Justice. In just two years, Queensland's youngest Attorney-General since Sir Samuel Griffith in $1874^{1}$ has implemented a significant package of law reforms. These reforms have been heavily and almost uniformly criticised by the profession, the judiciary, and the academy. ${ }^{2}$ This short note takes a discursive look at the young Attorney-General's contribution to Queen's land.

As a Life Member of the Australian Monarchists League, ${ }^{3}$ Mr Bleijie has made no secret of his support for Australia's current constitutional arrangements. This is not a problem per se. The Queensland government was elected by the people of Queensland and our system of representative government allows and encourages the government of the day to do what they wish. However, the full extent of Queensland's Glorious Revolution is somewhat remarkable in a time of budget emergency: ${ }^{4}$ the Attorney-General has found time to bring back Queen's Counsel; change the Queensland government logo back to the traditional Coat-of-Arms; name the new Supreme Court building after the reigning British monarch; and insist on passing legislation ratifying changes to the royal succession laws rather than simply allowing the Commonwealth to pass a blanket law.

The move back to Queen's Counsel has been the source of some debate in the profession. At the risk of perpetuating a debate that infringes Sayre's law that 'in any dispute the intensity of feeling is inversely proportional to the value of the issues at stake' - for the issue of postnominals for the top percentile of Queensland lawyers is very unimportant — it is worth noting these changes which form part of a pattern of Mr Bleijie's reforms. This note will first examine the reintroduction of QCs, before turning to the perplexing insistence of the Attorney-General to reclaim a direct relationship with the Queen.

\section{THE RETURN OF QUEEN'S COUNSEL}

Her Majesty's Learned Counsel in Law date to the late 16th century, when Sir Francis Bacon was appointed the first Queen's Counsel. ${ }^{5}$ But this appointment was not the first instance of privileging one member of the bar over another for reasons of professional merit. The office of

\footnotetext{
${ }^{1}$ Jarrod Bleijie, born 25 January 1982 and appointed Attorney-General on 3 April 2012, was 30 years 69 days old when sworn in. Sir Samuel Griffith, born 21 June 1845 and appointed Attorney-General (for the first time) on 3 August 1874, was 29 years 43 days old when sworn in.

${ }^{2}$ See, inter alia, Andrew Trotter and Harry Hobbs, 'The Great Leap Backward: Criminal Law Reform with the Hon Jarrod Bleijie' (2014) 36 Sydney Law Review 1; Andrew Trotter and Harry Hobbs, 'Under the Oak Tree: Institutional Reform in the Deep North' (2014) 88:5 Australian Law Journal (forthcoming); Andrew Trotter and Harry Hobbs, 'A historical perspective on juvenile justice reform in Queensland' (2014) 38 Criminal Law Journal 77; Harry Hobbs and Andrew Trotter, 'How Far Have We Really Come? Rolling Back Civil and Political Rights in Queensland' (Working Paper, 6 February 2014).

${ }^{3}$ Letter to Members, Liberty: The Official Newsletter of the Australian Monarchist League, January 2013, <http://www.monarchist.org.au/newsletterdetail.html?nlid=1358024555844961\&yr=2013>.

${ }^{4}$ See, eg, Queensland, Parliamentary Debates, Legislative Assembly, 4 June 2013, 1904 (Tim Nicholls, Treasurer).

5 These counsel are referred to in a Judges' Order of 1594: Dugdale Orig Jurid, 314. See William Holdsworth, $A$ History of English Law (Methuen, 2nd ed 1937) Vol 6, 472-5. See also Lord Mackay of Clashfern, Halsbury's Laws of England (Lexis Nexis, 5th ed, 2009) Vol 66, 256 [1039].
} 
Serjeant-at-law, or Order of the Coif, so named 'because of their distinctive head-dress' ${ }^{6}$ has been traced back to the twelfth century. ${ }^{7}$ The rise of QC and $\mathrm{KC}$ usurped the position of the Serjeants ${ }^{8}$ and, with the passing of Lord Lindley in 1921, the order died. ${ }^{9}$

The early QCs and KCs really were his or her 'Majesty's learned counsel in law'. They could not appear against the Crown without a licence, and were 'expected to give a favourable opinion as to the legality of the proposed exercise of the dispensing power' ${ }^{10} 0$ Indeed, Holdsworth suggests that even the granting of letters patent was not strictly an exercise in meritocracy: 'The members of the new order of King's Counsel were appointed from among lawyers whose politics the Government thought that it could trust'. ${ }^{11}$

The early history of Queens' Counsel in Queensland supports that contention. Charles Lilley was appointed Queensland's first Queen's Counsel in 1865, only four years after taking the bar. However, this was not evidence of a probing mind, razor sharp intellect and demonstrated excellence in practice, for Lilley was awarded this honour automatically by virtue of his holding the position of Attorney-General. Interestingly, the regulations which made conferral automatic to holders of political office were adopted by the Queensland government in 1865 - a government in which Charles Lilley was a vital part. His admission to the bar had followed a similar pattern:

Lilley had only come to the bar in 1861 , under a procedure whereby a solicitor of five years standing who qualified in classics or mathematics could be admitted as a barrister; a procedure made possible by the Supreme Court Constitution Amendment Act (Qld) 1861, a provision promoted by one Charles Lilley. ${ }^{12}$

Perhaps because of their curious history, or simply the rise in republican sentiment, beginning in the early 1990s, each state and territory successively dropped the archaic QC nomenclature and replaced it with 'SC', or 'senior counsel'. New South Wales was the first to do so in 1993, but Queensland soon followed in 1994. Following Queensland was the ACT in 1995, Victoria in 2000, Western Australia in 2001, Tasmania in 2005, the Northern Territory in 2007, and South Australia in 2008. In 2010 the Commonwealth too 'quietly' dropped the post-nominal QC in favour of SC. ${ }^{13}$ Before Bleijie's intervention only one jurisdiction had dropped QCs only to later return to them - New Zealand. ${ }^{14}$

On Friday 7 June 2013, Queensland joined with New Zealand, with Mr Bleijie 'welcom[ing] the return of a proud position in Queensland's legal and justice system' ${ }^{15}$ After 19 years, the title of Senior Counsel would be retired, and the title of Queen's Counsel would now be

\footnotetext{
${ }^{6}$ JM Bennett, 'Of silks and serjeants' (1978) 52 Australian Law Journal 264, 264.

${ }^{7}$ Alexander Pulling, The Order of the Coif (Legal Classics Library, Special Edition, 1989), 1.

${ }^{8}$ William Holdsworth, 'The rise of the order of King's Counsel and its effects on the legal profession' (1920) 36

Law Quarterly Review 212, 212.

${ }^{9}$ Bennett, above n 6, 267. It appears that only one Serjeant, William Sleigh, practised in Australia.

${ }^{10}$ Holdsworth, above n 8, 215.

${ }^{11}$ Ibid 218-219. In a clever turn of phrase Holdsworth styles them 'rising politicians of the legal variety', at 221.

12 Jeremy Finn, 'Political or professional honours: Queen's Counsel in Australia, 1839-1875' (1996) 2 AJLH 61, 70 (citations omitted).

${ }^{13}$ Chris Merritt, 'Government calls its new silks senior counsel, not Queen's counsel', The Australian (online) 9 July 2010.

${ }^{14}$ Lawyers and Conveyancers Amendment Act 2012 (NZ), amending the Lawyers and Conveyancers Act 2006 (NZ).

15 Jarrod Bleijie, 'QCs restored in Queensland' (Media Statement, 7 June 2013).
} 
reinstated for eminent barristers across the state. Both Victoria and the Commonwealth have since jumped on board, while New South Wales has announced that it will examine its options. ${ }^{16}$

The Queensland Attorney-General predicated his change on two points - competition in Asia, and clearing up apparent confusion:

Queensland silks now have the edge internationally, particularly in Asia where the use of QCs is preferred. This change gives Queensland leverage over other Australian states, which are competing for a share of the international market. The re-introduction of QCs will also help clear up confusion because a number of other titles are abbreviated to SC, including Special Counsel and the Star of Courage. ${ }^{17}$

It seems unlikely that potential clients in Asia are confusing Senior Counsel with either special counsel at law firms or recipients of the Star of Courage award for bravery. This is particularly so because both Singapore and Hong Kong have appointed SCs since 1997. The President of the NSW Bar Association, Phillip Boulten SC also discredited the marketing claim, noting that 'people get briefs in Asia and the rest of Australia based on the market's assessment of their ability to perform, not the initials after their names'. ${ }^{18}$ Nevertheless, 70 of the 74 SCs in Queensland (Commonwealth Attorney-General George Brandis among them) welcomed the change with open arms. ${ }^{19}$

However named, an institution of rank and precedence will continue to exist in the legal profession. There seems little point, however, in retaining the anachronistic link to the British monarch. ${ }^{20}$ It is difficult to know whether it is too early to be thankful that Mr Bleijie has not brought back the Serjeants — or their coif.

\section{THE ROYAL SUCCESSION LAWS}

Succession to the British throne is governed by common law and statute law. The Acts of Union $1707^{21}$ restated the Act of Settlement $1701^{22}$ and the Bill of Rights $1689,{ }^{23}$ which provided that the successors to the throne must be descendants of Princess Sophia, Electress of Hanover, while also excluding 'all Papists and persons marrying Papists'. ${ }^{24}$ At the same time, the common law male preference cognatic primogeniture meant that first-born sons took precedence over elder sisters, elder half-brothers and younger brothers. A female could only inherit the throne if all of her brothers were deceased, and none of them had left surviving legitimate descendants. This law developed out of the feudal system of Medieval Europe,

\footnotetext{
${ }^{16}$ Chris Merritt, 'Senior moments over as George Brandis opts for QCs', The Australian (Sydney), 11 March 2014; Nicola Berkovic, 'Queens count in the scramble to stand out', The Australian (Sydney), 7 February 2014.

${ }^{17}$ Bleijie, above n 15.

${ }^{18}$ Michael Pelly, 'States divide over restoration of “Queen's Counsel” title', The Australian (online) 14 June 2013.

${ }^{19}$ Michael Pelly, 'Silks all aflutter at the chance of royal U-turn', The Australian (online), 20 September 2013.

${ }^{20}$ Bennett, above n 6, 273.

${ }^{21}$ Union with Scotland Act 17066 Anne c 11; Union with England Act 1707 Anne c 7.

22 22. 12 \& 13 Will 3 c 2.

231 William \& Mary Sess 2 c 2.

${ }^{24}$ Union with Scotland Act 17066 Anne c 11, Art 2; Union with England Act 1707 Anne c 7, Art 2.
} 
where the central concern of matrimony became 'the protection and transmission of property and patrilineal control' ${ }^{25}$ Clearly today such laws are a breach of fundamental human rights. ${ }^{26}$

At the October 2011 Commonwealth Heads of Government Meeting in Perth, the question of royal succession was discussed. In what became known as the 'Perth Agreement', each nation agreed to amend the 'grossly arcane and offensive' ${ }^{27}$ laws of succession to the British throne. In short, male preference cognatic primogeniture would be replaced with full cognatic primogeniture for descendants of all persons in the line of succession born after 28 October 2011; marrying a Roman Catholic would no longer disqualify a person from succeeding to the Crown; and the ban on descendants of George II from marrying without the sovereign's consent would be partially repealed and limited to the six persons next in line. ${ }^{28}$ But the ban on Catholics and non-Protestants from becoming sovereign would remain. On 25 April 2013, the UK Parliament passed its Act, ${ }^{29}$ but the Statute of Westminster 1931 provides that each Commonwealth country is required to pass its own legislation in order for the changes to take effect. $^{30}$

The Commonwealth parliament has no express legislative power to deal with laws relating to succession. ${ }^{31}$ Additionally, because the Queen is a constituent part of the states, difficulties arise in relation to relying on the nationhood power to unilaterally alter succession. Thus, as Anne Twomey has argued, cooperative federalism per s 51 (xxxviii) of the Constitution and s 15 of the Australia Acts is regarded as the clearest and soundest approach. ${ }^{32}$ That is, all state parliaments would refer the laws of succession to the Commonwealth parliament to then enact that legislation.

At the Council of Australian Governments in December 2012, then Prime Minister Julia Gillard and five state Premiers reached the agreement that each parliament would pass legislation permitting the Federal parliament to complete the formality of altering the line of succession. Premier Campbell Newman disagreed. Newman and his Attorney-General cited s 7 of the Australia Act 1986 to proclaim that Queensland is a sovereign state and should therefore pass its own legislation amending its succession laws. ${ }^{33}$ On 13 February 2013, Jarrod Bleijie introduced Queensland's own Succession to the Crown Bill. He noted, 'Queensland is proud of its own relationship with the monarchy and as a sovereign state it should look to preserve this status at all times'. ${ }^{34}$ The then Attorney-General Mark Dreyfus summed up the situation well: 'The Queensland Government is more than welcome to pass its own face-saving legislation, secure in the knowledge that it will have no practical effect' ${ }^{35}$

\footnotetext{
${ }^{25}$ Sandra Berns, 'Women in English legal history: Subject (almost), object (irrevocably), person (not quite)' (1993) 12 University of Tasmania Law Review 26, 35. Ann Lyon, 'The place of women in European Royal Succession in the Middle Ages' (2006) 27 Liverpool Law Review 361.

${ }^{26}$ See, eg, the CEDAW, opened for signature 1 March 1980, 1249 UNTS 13 (entered into force 3 September 1981); Sex Discrimination Act 1984 (Cth).

${ }^{27}$ UK, Parliamentary Debates, House of Commons, 22 January 2013, vol 557, col 266 (Mark Durkan).

${ }^{28}$ Royal Marriages Act 1772 (UK) 12 Geo 3 c 11, s 2.

${ }^{29}$ Succession to the Crown Act 2013 (UK) c 21. For a detailed analysis, see Neil Parpworth, 'The Succession to the Crown Act 2013' (2013) 76 Modern Law Review 1070.

${ }^{30} 22 \& 23$ Geo. 5 c 4, Preamble. Anne Twomey, 'Changing the rules of succession to the throne' (Sydney Law School, Legal Studies Research Paper No 11/71, October 2011), 25.

31 . In 1936 the Federal government accepted legal advice that this is the case. See Twomey, above n 30, 17.

32 This is acknowledged by Queensland's Bill: See Succession to the Crown Bill 2013, Explanatory Notes, 2.

${ }^{33}$ Daniel Hurst, 'Right royal split over how to change succession rules', Brisbane Times (online), 7 December 2012.

${ }^{34}$ Amy Remeikis, 'Queen's land goes it alone', Brisbane Times (online), 14 February 2013.

35 Amy Remeikis, 'Queensland succession laws passed', Brisbane Times (online), 2 May 2013.
} 
On 2 May 2013, Queensland amended its Bill to add permission for the Commonwealth to act. $^{36}$ It was passed that same day. As of 26 March 2014, NSW, ${ }^{37}$ Tasmania $^{38}$ and Victoria ${ }^{39}$ have passed similar Acts.

\section{CONCLUSION}

In just 20 short months in office, Mr Bleijie has rolled back the creeping tide of republicanism that threatened to overrun Queensland. The Attorney-General has brought back the title of Queens Counsel for the most eminent barristers in the state; has named the new Law Courts building after Her Majesty Queen Elizabeth II; reinstated the traditional Coat of Arms; and, despite ultimately backing down, insisted on maintaining the state's personal relationship with the Queen by passing his own royal succession laws.

When in opposition, Mr Bleijie attacked the Bligh Labor government for straying from 'the significant issues of importance to' Queenslanders - issues that will 'save Queenslanders money', that 'will ease their cost-of-living pressures ... [that] will ... get our treasured AAA credit rating back'. ${ }^{40}$ I make no judgment as to whether the LNP government has been successful in these endeavours. I simply point out the effort that the Attorney-General has expended in putting the 'Queen' back in Queensland.

The recent election of Tony Abbott, a former executive director of Australians for a Constitutional Monarchy and a key player in the successful 'no' campaign against the 1999 Republic referendum, may be a harbinger of things to come at the Commonwealth level. In the wake of his electoral victory a portrait of the Queen was found hanging in the staff briefing room at the Department of Prime Minister and Cabinet, ${ }^{41}$ and in October, while commemorating the 100th anniversary of the Royal Australian Navy, Abbott remarked to Prince Harry, 'I regret to say that not every Australian is a monarchist, but today everyone feels like a monarchist' ${ }^{42}$ Late last year, I wondered what changes the new Prime Minister, a man who has previously described the monarchy as 'the tie that binds us together', ${ }^{43}$ and his newly reinstated QC Attorney-General have in store for Australia. We did not have to wait long.

On 25 March 2014 the Prime Minister reintroduced the title of knights and dames to the Order of Australia. While he did so without consulting his Cabinet, Abbott did consult both Brandis and Newman. ${ }^{44}$ Originally abolished by the Whitlam government, though reintroduced by Malcolm Fraser before finally being abolished again by Bob Hawke, the decision baffled many, including some staunchly monarchist state Premiers. Western Australian Premier Colin Barnett perhaps said it best: 'I think we've moved on. When people look back in history, the last vestiges of colonial history, you know, time to stand up Australia. Be a big country in your

\footnotetext{
${ }^{36}$ Succession to the Crown Act 2013 (Qld), s 14(1).

${ }^{37}$ Succession to the Crown (Request) Act 2013 (NSW).

${ }^{38}$ Succession to the Crown (Request) Act 2013 (Tas).

${ }^{39}$ Succession to the Crown (Request) Act 2013 (Vic).

${ }^{40}$ Queensland, Parliamentary Debates, Legislative Assembly, 30 November 2011, 3977 (Jarrod Bleijie).

${ }^{41}$ Noel Towell and Judith Ireland, 'Mystery Queen portrait hung in Tony Abbott's HQ', Sydney Morning Herald (Sydney) 30 September 2013.

42 Lauren Wilson, 'Abbott makes waves with republicans', The Australian (Sydney), 7 October 2013.

${ }^{43}$ Tony Abbott, 'Monarchy is the tie that binds us together', The Age (Melbourne), 29 November 2006.

${ }^{44}$ Steven Scott, 'Prime Minister Tony Abbott announces surprise return of British honours system', The Australian (Sydney), 26 March 2014.
} 
own right' ${ }^{45}$ Abbott's move certainly is, as Brandis notes, 'emblematic of the way in which Australia sees itself' ${ }^{46}$ After a long lull following the failure of the 1999 referendum, it is time that the Australian Republican Movement rises again.

Whether or not a republic is seen as mere symbolism, symbols are important and few would argue that politics does not possess a symbolic dimension. ${ }^{47}$ Democratic governments do not simply reflect the wants and preferences of their citizens, but shape those wants through symbols, myths, ritual and political language. ${ }^{48}$ Jarrod Bleijie and Tony Abbott's monarchist lurch is not an attempt to obfuscate their 'real' conservative agenda: this retrograde symbolism is their agenda. Republicans must fight back.

HARRY HOBBS is the Human Rights Legal and Policy Adviser at the ACT Human Rights Commission and a sessional tutor at the Australia National University

\footnotetext{
45 'Barnett: Knighthoods not welcomed in WA', WAToday (online), 26 March 2014.

${ }^{46}$ Lisa Cox, 'Tony Abbott bypassed colleagues on dames and knights move as Labor says it's a distraction from bad headlines', SMH (online), 26 March 2014.

${ }^{47}$ See, eg, Murray Edelman, Constructing the Political Spectacle (University of Chicago Press, 1988).

48 DeLysa Burnier, 'Constructing political reality' (1994) 47(1) Political Research Quarterly 239, 243.
} 